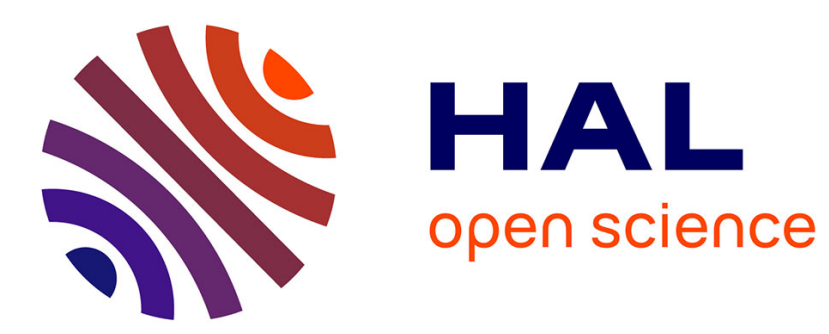

\title{
Improved efficiency of soil solarization for growth and yield of greenhouse tomatoes
}

G. Mauromicale, A. Lo Monaco, A.M.G. Longo

\section{To cite this version:}

G. Mauromicale, A. Lo Monaco, A.M.G. Longo. Improved efficiency of soil solarization for growth and yield of greenhouse tomatoes. Agronomy for Sustainable Development, 2010, 30 (4), 10.1051/agro/2010015. hal-00886494

\section{HAL Id: hal-00886494 \\ https://hal.science/hal-00886494}

Submitted on 1 Jan 2010

HAL is a multi-disciplinary open access archive for the deposit and dissemination of scientific research documents, whether they are published or not. The documents may come from teaching and research institutions in France or abroad, or from public or private research centers.
L'archive ouverte pluridisciplinaire $\mathbf{H A L}$, est destinée au dépôt et à la diffusion de documents scientifiques de niveau recherche, publiés ou non, émanant des établissements d'enseignement et de recherche français ou étrangers, des laboratoires publics ou privés. 


\title{
Research article
}

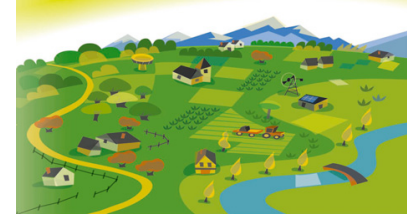

\section{Improved efficiency of soil solarization for growth and yield of greenhouse tomatoes}

\author{
G. Mauromicale*, A. Lo Monaco, A.M.G. Longo \\ Dipartimento di Scienze Agronomiche, Agrochimiche e delle Produzioni Animali, DACPA, Università degli Studi di Catania, via Valdisavoia 5, \\ 95123 Catania, Italy
}

(Accepted 17 March 2010)

\begin{abstract}
Soil solarization is a pre-planting treatment not based on chemicals, used in hot climates to control weeds and soil-borne pathogens. Its effectiveness has been widely demonstrated, for example, in the USA, Spain, Portugal, Egypt, Italy, Mexico, India and Iraq. However, an improvement in efficacy is needed before it can be widely adapted as a commercial practice. Supplementation of the soil with organic matter prior to solarization has been proposed as a management option, but its effectiveness has yet to be confirmed by any systematic study. Therefore, here we carried out a set of experiments in southern Italy over two seasons to study the effect of four levels of organic supplementation of 0 , 0.35 , 0.70 and $1.05 \mathrm{~kg} \mathrm{~m}^{-2}$ prior to solarization. Soil temperature and its chemical properties, as well as plant vegetation growth and fruit production were monitored for tomato plants grown under commercial greenhouse conditions. Organic supplementation increased the maximum soil temperature achieved through solarization by $3.9^{\circ} \mathrm{C}$ to $4.7^{\circ} \mathrm{C}$. At $5 \mathrm{~cm}$ below the soil surface, a temperature of over $52{ }^{\circ} \mathrm{C}$ prevailed for 22 to 23 days when $0.70 \mathrm{~kg} \mathrm{~m}^{-2}$ organic supplement was incorporated, and for 14 to 13 days in the presence of $0.35 \mathrm{~kg} \mathrm{~m}^{-2}$ supplement, but this temperature was attained only for one day in the absence of any supplement. Organic supplementation significantly increased the soil concentration of $\mathrm{NO}_{3}^{-}-\mathrm{N}$, exchangeable $\mathrm{K}_{2} \mathrm{O}, \mathrm{Ca}^{2+}$ and $\mathrm{Mg}^{2+}$ and electrical conductivity. Increased available $\mathrm{P}_{2} \mathrm{O}_{5}$ and total $\mathrm{N}$ at the end of the crop cycle were also associated with supplementation of solarized soil. Plant vegetative growth was improved by supplementation, with crop plant stem diameter enhanced by up to $18 \%$, above-ground vegetative fresh and dry weight by up to, respectively, 53 and $44 \%$, and the number of leaves per plant by up to $16 \%$. As the supplementation rate was raised from 0 to $0.70 \mathrm{~kg} \mathrm{~m}^{-2}$, fruit yield was increased by about $70 \%$ (from 4.9 to $8.3 \mathrm{~kg} \mathrm{plant}^{-1}$ ). Organic matter supplementation may provide the basis for a more favorable sink/source balance for tomato cropping. We conclude that organic supplementation represents a beneficial management measure to increase the effectiveness of soil solarization, and that these results provide encouragement for the future commercial application of this environmentally-friendly technique.
\end{abstract}

soil solarization / organic supplementation / soil properties / tomato / plant growth / fruit yield

\section{INTRODUCTION}

Fumigation with methyl bromide is heavily used as a means of reducing the incidence of weeds, soil-borne bacteria, fungi and nematodes. However, this chemical is well understood to be hazardous both to human and animal health, as well as being detrimental to the level of atmospheric ozone (Noling and Becker, 1994). As a result, under the revised Montreal Amendment (1997), its use since 2005 has only been allowed under certain defined "critical" conditions. There is a continuing and urgent need to identify alternative means for the control of soil-borne crop diseases. Chemical disinfection of the soil eradicates both beneficial and harmful biota, creating a vacuum, which is typically filled by pathogens (Gamliel

* Corresponding author: g.mauromicale@unict.it et al., 2000). As a result, the situation after treatment can become worse than that which prevailed before. Thus, nonchemical control, and in particular the use of methods which are non-injurious to the health of humans, domestic animals and the soil flora are clearly desirable (Gamliel and Stapleton, 1997).

Soil solarization represents a non-chemical, pre-planting method for controlling soil-borne diseases and pests. It consists of covering a wet soil with a transparent polyethylene sheet during the hot season, so that the soil becomes sufficiently heated to destroy invertebrate pests, weed seed and microbes (Katan et al., 1987). Compared to other methods, it has a number of advantages, since it does not create a biological vacuum, stimulates root growth, and increases crop yield (Chen et al., 1991; Gamliel et al., 2000). Although the 
principle of solarization is simple, its mode of action is complex, because it involves not only the destruction of propagules, but also generates shifts in microbial populations and activity, and changes the physical and chemical properties of the soil. The change mainly depends on increasing soil temperatures reached during solarization (Le Bihan et al., 1997; Mauromicale et al., 2005a), as a consequence of the greenhouse effect created but, also partially, due to the elimination of evaporation (Mahrer, 1979). Technical improvements in the efficacy of solarization could enable its use to be extended beyond its current limits. One possible avenue could be to incorporate more organic matter into the soil, prior to covering with the plastic sheet (Gamliel and Stapleton, 1997; Bacha et al., 2007; Piedra-Buena et al., 2007). This approach, named biofumigation (Katan, 2000), has received a great deal of attention in recent years (Gamliel et al., 2000; Ozores-Hampton et al., 2005).

Both temperature and soil moisture influence the rate of mineralization of soil organic matter, and this process can be promoted by solarization. Over the short term at least, the concentration of some soil mineral nutrients is increased in hot soils (Akhtar and Malik, 2000; Thuriès et al., 2000; Gelsomino et al., 2006), thus potentially enhancing plant growth (Chen et al., 2000). Long-term use of solarization and high doses of organic supplementation to solarized soil can, however, also have negative effects on both plant growth and beneficial soil biota populations (Assaf et al., 2006). Plant growth can be reduced when a crop is planted before the organic material has been fully degraded (Gamliel et al., 2000). Since both increases and decreases in the availability of plant nutrients have been attributed to soil solarization (Grünzweig et al., 1999; Thuriés et al., 2000), a definitive explanation of these mechanisms remains to be formulated. At present, only a modest research effort has been devoted to researching the effect of supplementation dosage, and no systematic study of crop growth and production in supplemented solarized soils has yet been reported. Such additional information is needed to improve the performance of soil solarization, and hence encourage its adoption in commercial practice. Thus, our objectives were to evaluate the effectiveness of organic supplementation before solarization on (i) the soil temperature during the mulching; (ii) the chemical properties of the soil; (iii) the growth and development of tomato; and (iv) its yield and yield components. The choice of tomato as the test crop was driven by its predominance as a field and greenhouse horticultural crop in the coastal areas of the Mediterranean basin (Tognoni and Serra, 2003).

\section{MATERIALS AND METHODS}

\subsection{Site, climate and soil}

Greenhouse experiments were conducted during the 20032004 and 2004-2005 seasons on the coastal plain south of Siracusa (Sicily), southern Italy $\left[37^{\circ} 03^{\prime} \mathrm{N}, 15^{\circ} 18^{\prime} \mathrm{E}\right.$, $10 \mathrm{~m}$ asl] in a moderately deep Calcixerollic Xerochrepts soil
(USDA Soil Taxonomy). The soil consisted of $15.5 \%$ clay, $29.1 \%$ silt and $55.4 \%$ sand. At the beginning of the trial, the soil $\mathrm{pH}$ was 7.6 , the organic matter content $2.0 \%$, the total nitrogen content $0.17 \%$, the level of available $\mathrm{P} 100 \mathrm{mg} \mathrm{kg}^{-1}$ and the level of exchangeable $\mathrm{K} 580 \mathrm{mg} \mathrm{kg}^{-1}$. The experimental field had been cultivated in a potato-lettuce-watermelon rotation for almost 15 years, and covered in plastic and used for tomato production for the last six years. The local climate is semi-arid/Mediterranean, with mild winters and hot, rainless summers. The mean 30-year maximum summer monthly temperatures are $29.6{ }^{\circ} \mathrm{C}$ (June), $32.5^{\circ} \mathrm{C}$ (July), $31.6{ }^{\circ} \mathrm{C}$ (August) and $27.3^{\circ} \mathrm{C}$ (September) (Servizio Idrografico, 1959-1998).

\subsection{Experimental design, organic supplementation and soil solarization}

In both seasons, the experiments were arranged in a randomized block design with four replications, using a plot size of $3 \times 15 \mathrm{~m}$. In the first season, three levels of organic supplementation were incorporated into the soil two days before solarization [0 ( $\mathrm{SsA}_{0}$, level 1), $0.35\left(\mathrm{SsA}_{0.35}\right.$, level 2$)$ and 0.70 $\left(\mathrm{SsA}_{0.70}\right.$, level 3) $\mathrm{kg} \mathrm{m}^{-2}$ ]. In the second season, to obtain a better estimate of the effects of the organic supplementation rate on the vegetative growth and fruit yield of tomato, the higher rate of $1.05 \mathrm{~kg} \mathrm{~m}^{-2}\left(\mathrm{SsA}_{1.05}\right.$, level 4) was added. The commercially formulated product Organor ${ }^{\circledR}$ (SCAM s.r.l., Modena - Italy), which contains organic C (32.0\%), humic $\mathrm{C}(10.0 \%)$, humic acid (17.2\%) and C/N (6.4), was used for supplementation. Organor, a pelleted preparation of sterilized cattle manure, chicken manure and roasted leather, was uniformly applied over the soil surface, and incorporated into the top $20 \mathrm{~cm}$ of the soil using a rotovator. One day prior to solarization, both the supplemented and non-supplemented soils were irrigated to field capacity to take advantage of the greater effectiveness of solarization in moist soils. In both seasons, solarization was achieved by covering the bare soil with a $30-\mu \mathrm{m}$ transparent polyethylene film ( $\geq 88 \%$ total visible transmittance and 20\% IR absorption) from 10 July to 9 September 2003, and from 2 July to 17 September 2004. The sheets were stretched close to the soil surface and then anchored. At the end of the solarization period, the sheets were carefully removed, avoiding as much as possible any disturbance to the soil.

The greenhouse, with a steel tubular structure and lateral windows along the sides, was covered by EVA (ethylene vinyl acetate) film of $200 \mu \mathrm{m}$ thickness and a total visible transmittance $\geq 86 \%$. In both seasons, the covering of the greenhouse was done after soil solarization, as is usual in the area.

\subsection{Plant material and management practices}

Five-week-old tomato plants [cv. Ikram $\mathrm{F}_{1}$ (Syngenta)] were planted on 7 October 2003 and 7 October 2004, using a within-row planting distance of $0.4 \mathrm{~m}$, and an interrow spacing of $1.15 \mathrm{~m}$ (overall planting density equivalent to 
$2.17 \mathrm{~m}^{-2}$ ). Lateral shoots were removed manually when required, and the resulting single stems were trained on wire. Drip irrigation was supplied when the accumulated daily evaporation reached $25 \mathrm{~mm}$. Bumblebees were introduced into the greenhouse to encourage pollination. Fruit harvesting continued from 29 January to 13 May 2004 [114 days after planting (DAP) until 219 DAP], and from 2 February to 27 May 2005 (118 DAP-232 DAP).

\subsection{Soil temperature measurement}

During the solarization period, in both seasons, the soil temperature was recorded every $30 \mathrm{~min}$, at 5 and $15 \mathrm{~cm}$ below the soil surface, using a number of thermistor sensors within a wire probe $(\mathrm{HI} 762 \mathrm{~W})$ buried in the center of the $\mathrm{SsA}_{0}, \mathrm{SsA}_{0.35}$ and $\mathrm{Ss}_{0.70}$ plots, and connected to a portable digital $\mathrm{HI} 98840$ microprocessor (Hanna Instruments, Padova, Italy).

\subsection{Soil analysis}

To aid in the interpretation of the first season's results, soil $\mathrm{pH}$, electrical conductivity (EC) and total $\mathrm{N}, \mathrm{NO}_{3}^{-}-\mathrm{N}$, exchangeable $\mathrm{K}_{2} \mathrm{O}$, available $\mathrm{P}_{2} \mathrm{O}_{5}, \mathrm{~K}^{+}, \mathrm{Ca}^{2+}, \mathrm{Mg}^{2+}$ and $\mathrm{Na}^{+}$ content were also measured the second season. For the $\mathrm{SsA}_{0}$, $\mathrm{SsA}_{0.35}$ and $\mathrm{SsA}_{0.70}$ treatments, three soil samples per plot were collected with a 4-cm (i.d.) core auger to a depth of 5$15 \mathrm{~cm}$, fractured into aggregates by hand pressure, air-dried and sieved $(<2 \mathrm{~mm})$. The first sampling date was in September 2004, two days after solarization was completed, and the second in June 2005, one day after the end of the cropping cycle. To minimize border effects of the solarization treatment, samples were taken from the middle of each plot. Samples destined for $\mathrm{NO}_{3}^{-}-\mathrm{N}$ content analysis were stored in a refrigerated container before transport to the laboratory and analyzed the following day. Soil $\mathrm{pH}, \mathrm{EC}$, total $\mathrm{N}$ and available $\mathrm{P}_{2} \mathrm{O}_{5}$ were analyzed using widely employed methods, and adopted in Italy as the UNICHIM (1985). The analysis of $\mathrm{NO}_{3}^{-}-\mathrm{N}$ and exchangeable $\mathrm{K}_{2} \mathrm{O}$ was carried out following procedures described in The Official Italian Methods of Soil Analysis (Gazzetta Ufficiale, 1992). $\mathrm{Ca}^{2+}, \mathrm{Mg}^{2+}$ and $\mathrm{Na}^{+}$analyses were obtained according to procedures approved by the Italian Society of Soil Science (SISS, 1985). Saturated paste was prepared by adding deionized water to approximately $200 \mathrm{~g}$ of soil sample as received until it reached a condition of complete saturation, as described by the guidelines of the Italian Society of Soil Science (SISS, 1985).

\subsection{Tomato growth and fruit production}

The diameter of the stem between the fourteenth and fifteenth leaves was measured non-destructively using a pair of calipers, and expressed as the mean of ten plants per replicate. Two measurements were made in each season - at 105 and 151 DAP in the first, and at 115 and 161 DAP in the second. The total numbers of leaves and fruit clusters per plant were
Table I. The effect of organic supplementation on soil temperature during solarization. The rate of supplementation was $0\left(\mathrm{SsA}_{0}\right), 0.35$ $\left(\mathrm{SsA}_{0.35}\right)$ or $0.70\left(\mathrm{SsA}_{0.70}\right) \mathrm{kg} \mathrm{m}^{-2}$, incorporated into the soil before solarization. The values represent the absolute and mean (in brackets) temperature maxima and minima during the solarization period (61 days in 2003 and 77 days in 2004) at two soil depths.

\begin{tabular}{|c|c|c|c|c|}
\hline \multirow{2}{*}{ Treatment } & \multicolumn{2}{|c|}{$5 \mathrm{~cm}$} & \multicolumn{2}{|c|}{$15 \mathrm{~cm}$} \\
\hline & $\mathrm{T}^{\circ} \max$ & $\mathrm{T}^{\circ} \min$ & $\mathrm{T}^{\circ} \max$ & $\mathrm{T}^{\circ} \min$ \\
\hline & \multicolumn{4}{|c|}{2003} \\
\hline $\mathrm{SsA}_{0}$ & $51.9(48.5)$ & $27.8(34.9)$ & $45.1(41.9)$ & $28.3(36.0)$ \\
\hline $\mathrm{SsA}_{0.35}$ & $53.8(50.3)$ & $29.2(36.7)$ & $47.1(43.7)$ & 29.7 (37.9) \\
\hline \multirow[t]{2}{*}{$\mathrm{SsA}_{0.70}$} & $56.6(52.0)$ & $30.5(36.5)$ & $49.4(45.4)$ & $29.4(37.4)$ \\
\hline & \multicolumn{4}{|c|}{2004} \\
\hline $\mathrm{SsA}_{0}$ & $52.9(49.4)$ & $26.2(31.8)$ & 46.9 (44.9) & $25.6(32.6)$ \\
\hline $\mathrm{SsA}_{0.35}$ & $54.7(51.2)$ & $26.7(33.5)$ & $48.7(46.8)$ & $27.1(34.5)$ \\
\hline $\mathrm{SsA}_{0.70}$ & $56.8(53.1)$ & $27.5(32.9)$ & $51.1(48.4)$ & $28.3(34.8)$ \\
\hline
\end{tabular}

recorded. Over the harvesting period, the number and weight of completely ripe fruits from ten plants per plot were noted. At the end of the growing period, the above-ground biomass of four plants per replicate was partitioned into stems and leaves, and respective dry weights were determined after their desiccation in a $65^{\circ} \mathrm{C}$ oven until a steady weight was attained. Dry matter partitioning between plant organs (stem, leaf and fruit) was also monitored.

\subsection{Statistical analysis}

The data were subjected to analysis of variance (ANOVA) where appropriate, and means were compared by Fisher's protected least significant difference (LSD) test $(P \leq 0.05)$. A polynomial (linear or quadratic) regression analysis was applied to define the relationship between supplementation treatment and various crop parameters. Fruit yield rate was estimated from the slope of the linear regression fitted between accumulation of ripe fruit fresh weight at each harvest and harvest date expressed in days. The significance of differences between regression coefficients was evaluated by a parallelism test (Ottaviano, 1977).

\subsection{Temperature during the crop cycle}

Over the period from October to early May, the mean temperature maxima and minima in the greenhouse were $33.3^{\circ} \mathrm{C}$ and $18.8^{\circ} \mathrm{C}$, respectively, in the first season, and $31.6{ }^{\circ} \mathrm{C}$ and $18.0^{\circ} \mathrm{C}$ in the second season.

\section{RESULTS AND DISCUSSION}

\subsection{Soil temperature}

In both seasons and at both depths, the incorporation of organic supplementation increased the soil temperature during solarization (Tab. I). In the $\mathrm{SsA}_{0.70}$ treatment, a maximum 
Table II. The effect of organic supplementation on the number of days during which the soil temperature exceeded $42{ }^{\circ} \mathrm{C}, 44{ }^{\circ} \mathrm{C}, 46{ }^{\circ} \mathrm{C}, 48^{\circ} \mathrm{C}$, $50{ }^{\circ} \mathrm{C}, 52{ }^{\circ} \mathrm{C}$ or $54{ }^{\circ} \mathrm{C}$ at two soil depths. The rate of supplementation was $0\left(\mathrm{SsA}_{0}\right), 0.35\left(\mathrm{SsA}_{0.35}\right)$ or $0.70\left(\mathrm{SsA}_{0.70}\right) \mathrm{kg} \mathrm{m}^{-2}$, incorporated into the soil before solarization.

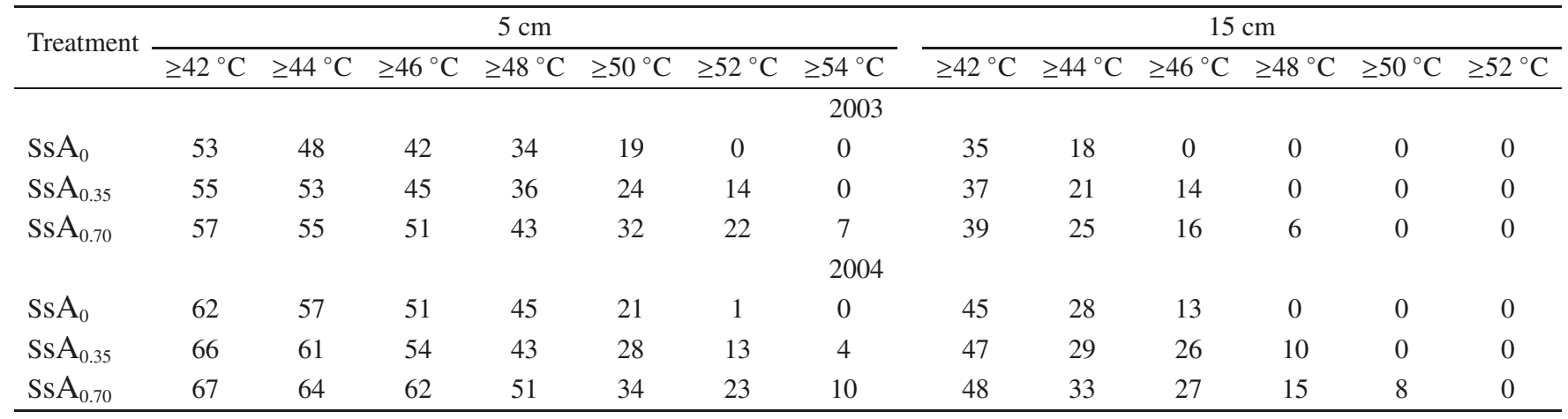

temperature of $>56^{\circ} \mathrm{C}$ at a depth of $5 \mathrm{~cm}$ was reached in both years. These levels were $2.8^{\circ} \mathrm{C}$ (first season) and $2.1{ }^{\circ} \mathrm{C}$ (second season) higher than those achieved at the same depth in $\mathrm{SsA}_{0.35}$, and $4.7{ }^{\circ} \mathrm{C}$ (first season) and $3.9^{\circ} \mathrm{C}$ (second season) higher than in $\mathrm{SsA}_{0}$. The outcome of the $\mathrm{SsA}_{0.35}$ experiment was consistent with the effect of a $2-3{ }^{\circ} \mathrm{C}$ increase in the temperature of a solarized soil amended with chicken compost over that experienced in a solarized, non-supplemented soil (Gamliel and Stapleton, 1993).

The magnitude of this increase in maximum temperature was maintained, almost unaltered, at a depth of $15 \mathrm{~cm}$ in both years. The maximum soil temperature (both absolute and average) was consistently higher in $\mathrm{Ss}_{0.70}$ than in $\mathrm{SsA}_{0.35}$, which in turn was higher than in $\mathrm{SsA}_{0}$ (Tab. I).

The number of days during which the maximum soil temperature equaled or exceeded $42,44,46,48,50,52$ and $54{ }^{\circ} \mathrm{C}$ at depths of 5 and $15 \mathrm{~cm}$ is shown in Table II. A temperature $\geq 52{ }^{\circ} \mathrm{C}$ at $5 \mathrm{~cm}$ was recorded for 22 (first season) and 23 (second season) days in $\mathrm{Ss}_{0.70}$, for 14 and 13 days in $\mathrm{SsA}_{0.35}$, and for 0 and 1 days in $\mathrm{SsA}_{0}$ (Tab. II). This rise in temperature is probably sufficient to control many pathogenic organisms, and is likely to affect the activity, ecology and population dynamics of the whole soil biota (Stotzky, 1974; Gamliel et al., 2000; Gelsomino and Cacco, 2006). In addition, the elevated temperature encourages the breakdown of organic matter, with the consequent accumulation of volatile compounds damaging to many soil-borne pathogens and weed seeds, but which simultaneously stimulate the activity of antagonistic micro-organisms, and so provide a further layer of control over weeds, soil-borne plant pathogens and root nematodes (Oka et al., 2007). In the rhizosphere of lettuce plants grown in solarized soil supplemented with chicken manure compost, the representation of both Bacillus spp. and fluorescent Pseudomonads was increased (Gamliel and Stapleton, 1993), while more recently, DNA fingerprinting analyses have shown that solarization of supplemented soils has a marked effect on the population structure of the soil biota (Gelsomino and Cacco, 2006).

The diurnal fluctuation in soil temperature at 5 and $15 \mathrm{~cm}$ below the surface is illustrated in Figure 1, which shows how the differences between the supplementation treatments were most evident between 12.00 and $16.00 \mathrm{~h}$.

\subsection{Chemical properties of soil}

We have shown here that organic supplementation prior to solarization results in an increase in both the availability of soluble nutrients $\left(\mathrm{NO}_{3}^{-}-\mathrm{N}, \mathrm{K}_{2} \mathrm{O}, \mathrm{Ca}^{2+}, \mathrm{Mg}^{2+}\right)$ and the level of EC (Tab. III). The concentration of nutrients and the EC were both directly related to the extent to which the soil was heated, which, in turn, was governed by the supplementation rate at least up to $0.70 \mathrm{~kg} \mathrm{~m}^{-2}$. Similar increases in soil nutrient concentration following soil solarization have been documented by Stapleton et al. (1985) and Mauromicale et al. (2005b). These increases occurred where soil temperature was increased, but not when wet, film-covered soil was insulated from solar heating (Stapleton et al., 1985), an observation which confirms that the increase in soil nutrient content is temperature-driven. Chen et al. (1991) have suggested that a soil which has been solarized over the summer may not maintain its level of $\mathrm{NO}_{3}^{-}-\mathrm{N}$ over the winter. The present study shows similarly that in solarized, supplemented soils, the concentrations of $\mathrm{NO}_{3}^{-}-\mathrm{N}, \mathrm{Ca}^{2+}, \mathrm{Mg}^{2+}, \mathrm{Na}^{+}$and $\mathrm{EC}$ all decreased, by varying degrees, between the first and the second sampling date, whereas the total $\mathrm{N}$ content, exchangeable $\mathrm{K}_{2} \mathrm{O}$ and available $\mathrm{P}_{2} \mathrm{O}_{5}$ increased. The highest increases were recorded in the $\mathrm{SsA}_{0.70}$ plots (Tab. III). Overall, supplementation was beneficial for soil fertility, as it helped maintain the level of soil nutrients.

\subsection{Vegetative plant growth}

The improvement in the chemical and physical condition of the soil achieved by organic supplementation prior to solarization promotes plant growth. There appears to be a significant positive correlation between the growth response and supplementation rate. In both seasons, the stem diameter, vegetative fresh and dry weight and the number of leaves per plant 
Temperature $\left({ }^{\circ} \mathrm{C}\right)$

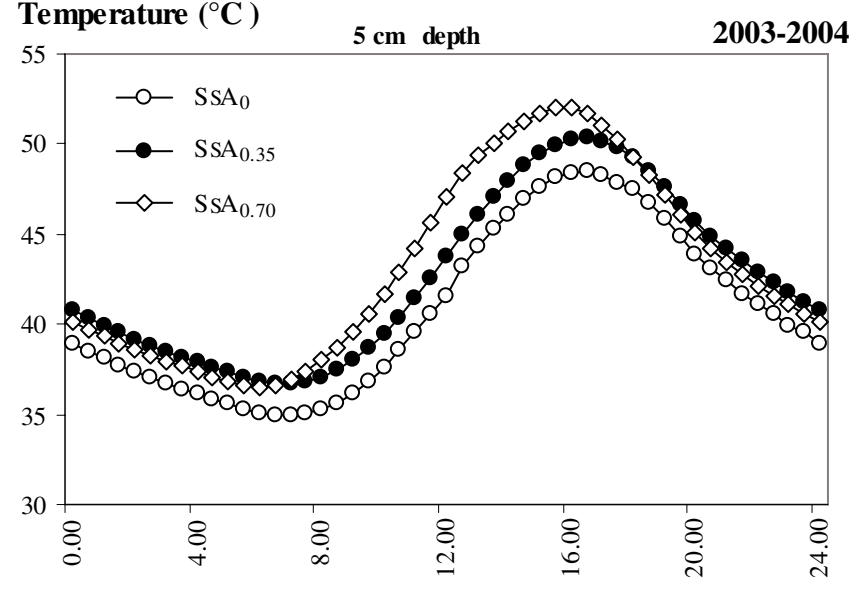

Time (Hours)

Temperature $\left({ }^{\circ} \mathrm{C}\right)$

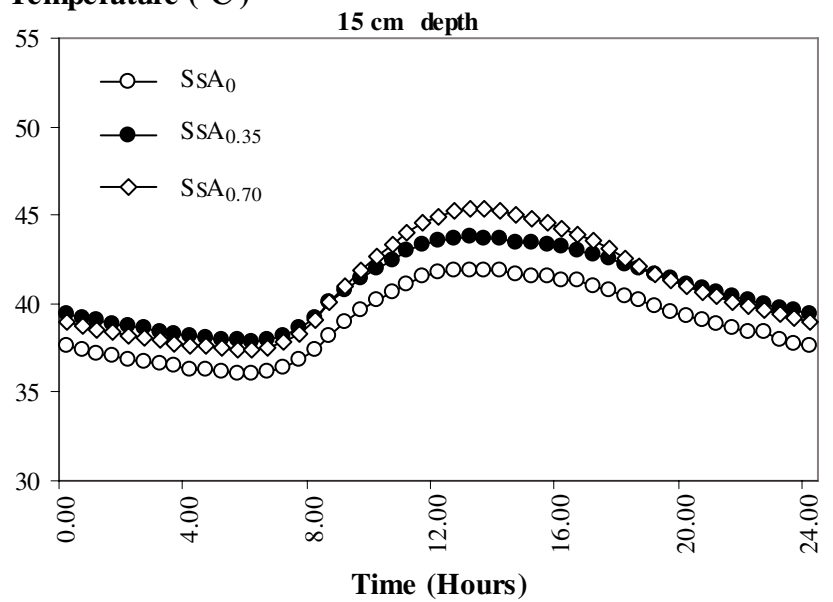

Temperature $\left({ }^{\circ} \mathrm{C}\right)$

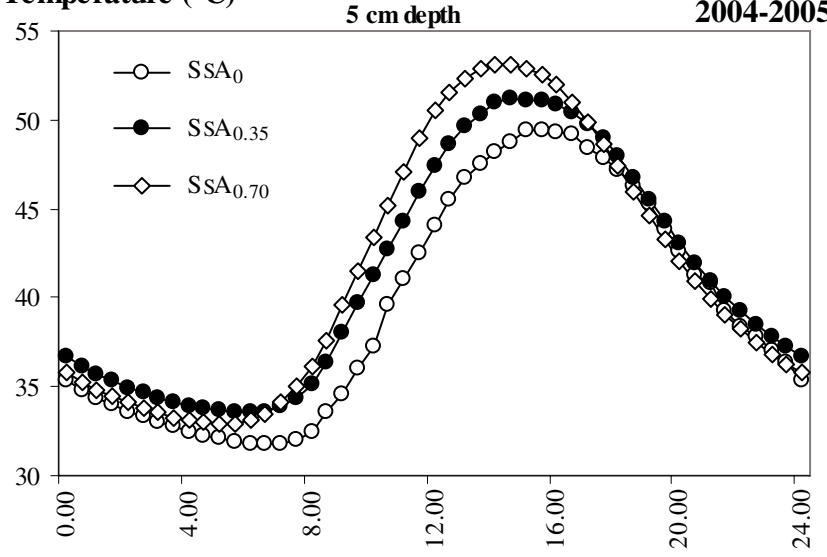

Time (Hours)

Temperature $\left({ }^{\circ} \mathrm{C}\right)$

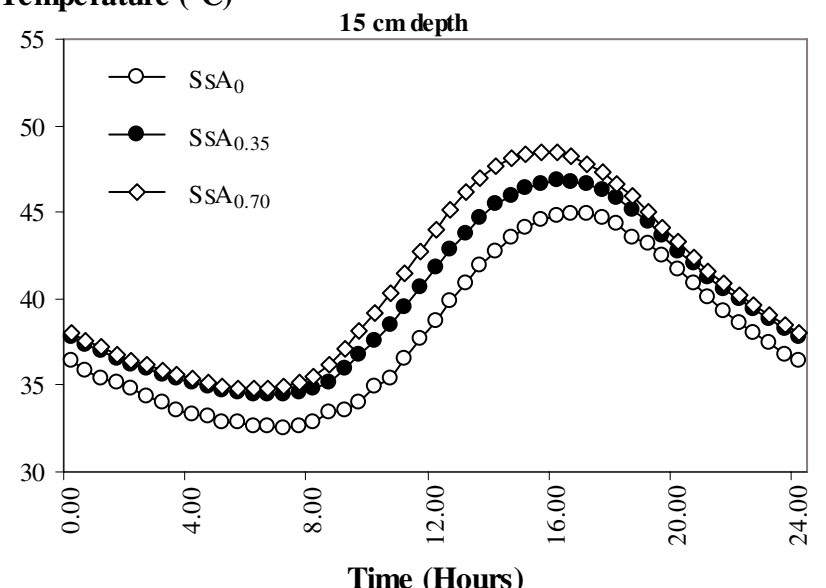

Figure 1. The effect of organic supplementation on diurnal trends in the soil temperature at two soil depths. Each symbol represents a half-hourly mean temperature over the entire period of soil solarization. The rate of supplementation was $0\left(\mathrm{SsA}_{0}\right), 0.35\left(\mathrm{SsA}_{0.35}\right)$ or $0.70\left(\mathrm{SsA}_{0.70}\right) \mathrm{kg} \mathrm{m}^{-2}$, incorporated into the soil before solarization.

all increased linearly with supplementation rate (Tabs. IV, V). Vegetative fresh and dry weight increased by, respectively, $27 \%$ and $22 \%$ as the supplementation rate increased from 0 to $0.70 \mathrm{~kg} \mathrm{~m}^{-2}$ in the first season, and by $53 \%$ and $44 \%$ as it was increased from 0 to $1.05 \mathrm{~kg} \mathrm{~m}^{-2}$ in the second (Tab. V). The greater plant growth was balanced, in the sense that it led to a significant increase in both the number of fruit clusters per plant and the number of fruits per plant (Tabs. V, VI).

The dry matter percentage of stem + leaves, on the contrary, linearly decreased with the increase in amendment rate, in both seasons (Tab. V). No evidence of any phytotoxic effect of supplementation was observed in either season.

\subsection{Fruit yield and its components}

All fruit yield parameters increased linearly with the rate of supplementation (Tab. VI). As the rate increased from 0 to $0.70 \mathrm{~kg} \mathrm{~m}^{-2}$, total fresh fruit yield increased by $69 \%(4.8$ to $8.1 \mathrm{~kg} \mathrm{plant}^{-1}$ ) in the first season, and by $73 \%$ (4.9 to $8.5 \mathrm{~kg} \mathrm{plant}^{-1}$ ) in the second (Tab. VI). At the higher rate of $1.05 \mathrm{~kg} \mathrm{~m}^{-2}$, however, fruit yield was only $88 \%$ of that achieved in $\mathrm{SsA}_{0.70}$, resulting in the significance $(P \leq 0.05)$ of the quadratic term in the regression (Tab. VI). It was clear that the most productive regime with respect to fruit yield $\left(\mathrm{SsA}_{0.70}\right)$ did not correspond with the one promoting the largest increase in plant growth ( $\left.\mathrm{SsA}_{1.05}\right)$. The positive effects of supplementation on fruit yield were due mostly to a higher number of fruits per plant, rather than to any increase in mean fruit weight (Tab. VI). Plants grown in supplemented soil produced 67.7 (first season) and 71.1 (second season) fruits per plant, with a mean fruit weight of, respectively, 113.5 and $112.3 \mathrm{~g}$; in comparison, those grown in non-supplemented soil yielded only 49.6 and 52.3 fruits per plant, with a mean weight of 110.0 and $103.6 \mathrm{~g}$ (Tab. VI). The supplementation rate led to a significant increase in both the number of fruit clusters per plant and the mean number of fruits per cluster (Tabs. V, VI), positively balancing the greater plant growth. 
Table III. The effect of organic supplementation on soil $\mathrm{pH}$, electrical conductivity (EC) and element concentration in soil extracts during the 2004-2005 season. The rate of supplementation was $0\left(\mathrm{SsA}_{0}\right), 0.35\left(\mathrm{SsA}_{0.35}\right)$ or $0.70\left(\mathrm{SsA}_{0.70}\right) \mathrm{kg}^{-2}$, incorporated into the soil before solarization.

\begin{tabular}{|c|c|c|c|c|c|c|c|c|c|}
\hline \multirow[t]{2}{*}{ Parameter } & & \multicolumn{3}{|c|}{ September 2004 } & \multirow{2}{*}{ Significance } & \multicolumn{3}{|c|}{ June $2005^{2}$} & \multirow{2}{*}{ Significance } \\
\hline & & $\mathrm{SsA}_{0}$ & SsA $_{0.35}$ & $\mathrm{SsA}_{0.70}$ & & $\mathrm{SsA}_{0}$ & $\operatorname{SsA}_{0.35}$ & $\mathrm{SsA}_{0.70}$ & \\
\hline $\mathrm{pH}$ & & 7.51 & 7.59 & 7.63 & NS & 7.87 & 7.99 & 8.18 & NS \\
\hline $\mathrm{K}_{2} \mathrm{O}$ (exchangeable) & $\mathrm{mg} \mathrm{kg}^{-1}$ & $563 \mathrm{c}$ & $622 \mathrm{~b}$ & $668 \mathrm{a}$ & $* *$ & $721 \mathrm{c}$ & $780 \mathrm{~b}$ & $900 \mathrm{a}$ & $* *$ \\
\hline $\mathrm{P}_{2} \mathrm{O}_{5}$ (available) & $\mathrm{mg} \mathrm{kg}^{-1}$ & 130 & 132 & 135 & NS & $155 \mathrm{~b}$ & $167 \mathrm{~b}$ & $221 \mathrm{a}$ & $*$ \\
\hline $\mathrm{NO}_{3}^{-}-\mathrm{N}$ & $\mathrm{mg} \mathrm{kg}^{-1}$ & $0.5 \mathrm{c}$ & $1.1 \mathrm{~b}$ & $1.5 \mathrm{a}$ & $* *$ & $0.5 \mathrm{~b}$ & $0.6 \mathrm{~b}$ & $1.0 \mathrm{a}$ & $*$ \\
\hline Total-N & $\%$ & 1.4 & 1.8 & 1.6 & NS & $1.8 \mathrm{~b}$ & $2.3 \mathrm{ab}$ & $2.9 \mathrm{a}$ & $*$ \\
\hline \multicolumn{10}{|l|}{ Saturated soil paste } \\
\hline $\mathrm{Ca}$ & meq $\mathrm{L}^{-1}$ & $32.6 \mathrm{c}$ & $54.2 \mathrm{~b}$ & $73.4 \mathrm{a}$ & $* * *$ & $14.8 \mathrm{c}$ & $17.7 \mathrm{~b}$ & $21.2 \mathrm{a}$ & $* *$ \\
\hline $\mathrm{Mg}$ & meq $\mathrm{L}^{-1}$ & $5.9 \mathrm{c}$ & $8.7 \mathrm{~b}$ & $10.2 \mathrm{a}$ & $* *$ & $2.3 \mathrm{c}$ & $4.1 \mathrm{~b}$ & $3.3 \mathrm{a}$ & $* *$ \\
\hline $\mathrm{Na}$ & meq $\mathrm{L}^{-1}$ & $24.9 \mathrm{c}$ & $29.5 \mathrm{~b}$ & $33.9 \mathrm{a}$ & $*$ & $7.7 \mathrm{~b}$ & $9.5 \mathrm{a}$ & $9.3 \mathrm{a}$ & $*$ \\
\hline E C & $\mathrm{dS} \mathrm{m} \mathrm{m}^{-1}$ & $4.6 \mathrm{c}$ & $6.8 \mathrm{~b}$ & $8.4 \mathrm{a}$ & $* *$ & $2.2 \mathrm{c}$ & $2.8 \mathrm{~b}$ & $3.1 \mathrm{a}$ & $* *$ \\
\hline \multicolumn{10}{|l|}{ Exchangeable cations } \\
\hline $\mathrm{K}$ & meq $100 \mathrm{~g}^{-1}$ & $1.2 \mathrm{~b}$ & $1.3 \mathrm{~b}$ & $1.5 \mathrm{a}$ & $*$ & $1.5 \mathrm{~b}$ & $1.7 \mathrm{~b}$ & $2.1 \mathrm{a}$ & $*$ \\
\hline $\mathrm{Ca}$ & meq $100 \mathrm{~g}^{-1}$ & $26.3 \mathrm{~b}$ & $27.3 \mathrm{~b}$ & $29.1 \mathrm{a}$ & $*$ & 25.2 & 26.0 & 27.7 & NS \\
\hline $\mathrm{Mg}$ & meq $100 \mathrm{~g}^{-1}$ & $3.2 \mathrm{c}$ & $3.5 \mathrm{~b}$ & $3.6 \mathrm{a}$ & $* *$ & 3.2 & 3.3 & 3.3 & NS \\
\hline $\mathrm{Na}$ & meq $100 \mathrm{~g}^{-1}$ & 1.8 & 2.8 & 2.4 & NS & 1.6 & 1.8 & 1.7 & NS \\
\hline C.S.C. & & $33.8 \mathrm{~b}$ & $34.1 \mathrm{~b}$ & $36.9 \mathrm{a}$ & $*$ & 32.4 & 32.8 & 34.5 & NS \\
\hline
\end{tabular}

${ }^{1}$ After solarization e before the tomato crop cycle.

${ }^{2}$ After the tomato crop cycle. Different letters within the same row show significant differences (LSD test, $P \leq 0.05$ ). *, **, ***, NS, significant difference at $P \leq 0.05,0.01,0.001$ and not significant, respectively.

Table IV. The effect of organic supplementation on stem diameter over two crop seasons. The rate of supplementation was $0\left(\mathrm{SsA}_{0}\right)$, $0.35\left(\mathrm{SsA}_{0.35}\right), 0.70\left(\mathrm{SsA}_{0.70}\right)$ or $1.05\left(\mathrm{SsA}_{1.05}\right) \mathrm{kg} \mathrm{m}^{-2}$, incorporated into the soil before solarization.

\begin{tabular}{|c|c|c|}
\hline \multirow[t]{3}{*}{ Treatment } & \multicolumn{2}{|c|}{$\begin{array}{l}\text { Stem diameter } \\
(\mathrm{mm})\end{array}$} \\
\hline & \multicolumn{2}{|c|}{ 2003-2004 } \\
\hline & $105 D A P^{1}$ & $151 D A P$ \\
\hline $\mathrm{SsA}_{0}$ & $12.7 \mathrm{a}$ & $15.2 \mathrm{c}$ \\
\hline $\mathrm{SsA}_{0.35}$ & $12.9 \mathrm{a}$ & $16.1 \mathrm{~b}$ \\
\hline $\mathrm{Ss}_{0.70}$ & $13.2 \mathrm{a}$ & $17.4 \mathrm{a}$ \\
\hline$F$ & N.S. & $* * *$ \\
\hline \multirow{3}{*}{$\mathrm{L}$} & $* *$ & $* *$ \\
\hline & \multicolumn{2}{|c|}{ 2004-2005 } \\
\hline & $115 D A P$ & $161 D A P$ \\
\hline $\mathrm{SsA}_{0}$ & $12.7 \mathrm{~d}$ & $16.0 \mathrm{~d}$ \\
\hline $\mathrm{SsA}_{0.35}$ & $13.4 \mathrm{c}$ & $16.3 \mathrm{c}$ \\
\hline $\operatorname{Ss}_{0.70}$ & $14.2 \mathrm{~b}$ & $18.0 \mathrm{~b}$ \\
\hline $\mathrm{Ss}_{1.05}$ & $15.0 \mathrm{a}$ & $18.7 \mathrm{a}$ \\
\hline$F$ & $* * *$ & $* * *$ \\
\hline $\mathrm{L}$ & $* * *$ & $* * *$ \\
\hline
\end{tabular}

${ }^{1}$ DAP $=$ Days after planting.

Different letters within the same row show significant differences (LSD test, $P \leq 0.05$ ). Significance levels for linear (L) regression term (quadratic and cubic was not significant). $* *, * * *$, NS, significant difference at $P \leq 0.01,0.001$ and not significant, respectively. F, variance ratio.

Notably, the overall fruit yield levels of $177 \mathrm{t} \mathrm{ha}^{-1}$ in the first season and $184 \mathrm{t} \mathrm{ha}^{-1}$ in the second season were, respectively, $149 \%$ and $159 \%$ above the long-term average for greenhousegrown tomatoes in Italy (ISTAT, 2006-2007).
The effect of organic supplementation was, therefore, more marked on the reproductive than on the vegetative phase of the crop. Thus it appears that solarized, supplemented soils provide the basis for a more favorable sink/source balance. The fruit dry weight/leaf dry weight ratio increased linearly with the supplementation rate. For $\mathrm{SsA}_{0.70}$, this ratio was almost twice that for $\mathrm{SsA}_{0}$. On the other hand, the $\mathrm{SsA}_{1.05}$ treatment was less effective than $\mathrm{SsA}_{0.70}$ (Tab. VI). In both seasons, the fruit yield rate was clearly improved by supplementation up to $0.70 \mathrm{~kg} \mathrm{~m}^{-2}$. The slope of the regression relating fruit yield accumulation to harvest date increased significantly $(P \leq 0.01)$ from $0.051\left(\mathrm{SsA}_{0}\right)$ to $0.059\left(\mathrm{SsA}_{0.35}\right)$ to $0.084\left(\mathrm{SsA}_{0.70}\right)$ in the first season, and from $0.046\left(\mathrm{SsA}_{0}\right)$ to $0.057\left(\mathrm{SsA}_{0.35}\right)$ to $0.081\left(\mathrm{Ss}_{0.70}\right)$ in the second season. However, the slope was reduced to 0.072 for $\mathrm{SsA}_{1.05}$ (Fig. 2).

\section{CONCLUSION}

Under the Mediterranean conditions typical of southern Italy, the addition of organic supplementation before solarization has proven to be an excellent means of improving the chemical properties of the soil and, consequently, the plant growth and fruit yield of greenhouse-grown tomatoes.

We have shown that the improvement in the soil condition brought about by organic supplementation can also play a role in determining levels of photosynthesis and chlorophyll fluorescence as well as the efficiency of assimilate translocation from the leaves to the fruit (unpublished data). The fruit dry weight/leaf dry weight ratio was approximately doubled in the $\mathrm{SsA}_{0.70}$ treatment as compared with $\mathrm{SsA}_{0}$. The mechanism(s) 
Table V. The effect of organic supplementation on stem and leaf fresh and dry weight, dry matter percentage, and the total numbers of leaves and fruit clusters during two seasons. The rate of supplementation was $0\left(\mathrm{SsA}_{0}\right), 0.35\left(\mathrm{SsA}_{0.35}\right), 0.70\left(\mathrm{SsA}_{0.70}\right)$ or $1.05\left(\mathrm{SsA}_{1.05}\right) \mathrm{kg}^{-2}$, incorporated into the soil before solarization.

\begin{tabular}{|c|c|c|c|c|c|}
\hline \multirow[b]{2}{*}{ Treatment } & \multicolumn{3}{|c|}{ Stem + leaf } & \multirow[b]{2}{*}{$\begin{array}{c}\text { Leaf } \\
\left(\text { n plant }^{-1}\right)\end{array}$} & \multirow[b]{2}{*}{$\begin{array}{c}\text { Fruit cluster } \\
\left(\mathrm{n} \text { plant }^{-1}\right)\end{array}$} \\
\hline & $\begin{array}{c}\text { Fresh weight } \\
\left(\mathrm{g} \text { plant }^{-1}\right)\end{array}$ & $\begin{array}{c}\text { Dry weight } \\
\left(\mathrm{g} \text { plant }^{-1}\right)\end{array}$ & $\begin{array}{c}\text { Dry matter } \\
(\%)\end{array}$ & & \\
\hline & & & $2003-2004$ & & \\
\hline $\mathrm{SsA}_{0}$ & $1100 \mathrm{~b}$ & $163 \mathrm{~b}$ & $14.8 \mathrm{a}$ & $31 \mathrm{~b}$ & $9 \mathrm{c}$ \\
\hline $\mathrm{SsA}_{0.35}$ & $1113 \mathrm{~b}$ & $164 \mathrm{~b}$ & $14.7 \mathrm{a}$ & $32 \mathrm{~b}$ & $10 \mathrm{~b}$ \\
\hline $\operatorname{SsA}_{0.70}$ & $1393 \mathrm{a}$ & $199 a$ & $14.3 \mathrm{~b}$ & $35 \mathrm{a}$ & $12 \mathrm{a}$ \\
\hline$F$ & $* * *$ & $* * *$ & $*$ & $* *$ & $* * *$ \\
\hline $\mathrm{L}$ & $* *$ & $* *$ & $* *$ & $* *$ & $* *$ \\
\hline & & & 2004-2005 & & \\
\hline $\mathrm{SsA}_{0}$ & $1114 \mathrm{~d}$ & $168 \mathrm{~d}$ & $15.1 \mathrm{a}$ & $31 \mathrm{~d}$ & $9 \mathrm{~d}$ \\
\hline $\mathrm{SsA}_{0.35}$ & $1288 \mathrm{c}$ & $192 \mathrm{c}$ & $14.9 \mathrm{a}$ & $32 \mathrm{c}$ & $10 \mathrm{c}$ \\
\hline $\mathrm{SsA}_{0.70}$ & $1584 \mathrm{~b}$ & $223 b$ & $14.1 \mathrm{~b}$ & $35 \mathrm{~b}$ & $12 \mathrm{a}$ \\
\hline $\mathrm{SsA}_{1.05}$ & $1709 \mathrm{a}$ & $242 \mathrm{a}$ & $14.2 \mathrm{~b}$ & $36 a$ & $11 \mathrm{~b}$ \\
\hline$F$ & $* * *$ & $* * *$ & $*$ & $* * *$ & $* * *$ \\
\hline $\mathrm{L}$ & $* * *$ & $* * *$ & $* *$ & $* * *$ & $* * *$ \\
\hline
\end{tabular}

Different letters within the same row show significant differences (LSD test, $P \leq 0.05$ ). Significance levels for linear (L) regression term (quadratic and cubic was not significant). *,****, significant difference at $P \leq 0.05,0.01$ and 0.001 , respectively. F, variance ratio.

Table VI. The effect of organic supplementation on total fruit yield, the number of fruits per plant and per cluster, mean fruit weight and fruit dry weight/leaf dry weight over two seasons. The rate of supplementation was $0\left(\mathrm{SsA}_{0}\right), 0.35\left(\mathrm{SsA}_{0.35}\right), 0.70\left(\mathrm{SsA}_{0.70}\right)$ or $1.05\left(\mathrm{SsA}_{1.05}\right) \mathrm{kg} \mathrm{m}^{-2}$, incorporated into the soil before solarization.

\begin{tabular}{|c|c|c|c|c|c|}
\hline Treatment & $\begin{array}{l}\text { Total fresh } \\
\text { fruit yield } \\
\left(\mathrm{kg} \mathrm{plant}^{-1}\right)\end{array}$ & $\left(\right.$ n plant $\left.{ }^{-1}\right)$ & $\begin{array}{c}\text { Fruit average } \\
\text { weight } \\
\text { (g) }\end{array}$ & $\begin{array}{c}\text { Fruit per } \\
\text { cluster } \\
\text { (n) }\end{array}$ & $\begin{array}{c}\text { Fruit dry } \\
\text { weight/Leaf } \\
\text { dry weight }\end{array}$ \\
\hline & & & 2003-2004 & & \\
\hline $\mathrm{SsA}_{0}$ & $4.8 \mathrm{c}$ & $49.6 \mathrm{c}$ & $110.0 \mathrm{~b}$ & $5.4 \mathrm{c}$ & $2.17 \mathrm{c}$ \\
\hline $\mathrm{SsA}_{0.35}$ & $5.6 \mathrm{~b}$ & $58.7 \mathrm{~b}$ & $109.0 \mathrm{~b}$ & $5.9 \mathrm{~b}$ & $2.81 \mathrm{~b}$ \\
\hline $\mathrm{SsA}_{0.70}$ & $8.1 \mathrm{a}$ & $76.8 \mathrm{a}$ & $118.1 \mathrm{a}$ & $6.5 \mathrm{a}$ & $4.56 \mathrm{a}$ \\
\hline$F$ & $* * *$ & $* * *$ & $* * *$ & $* * *$ & $* * *$ \\
\hline $\mathrm{L}$ & $* * *$ & $* * *$ & $* *$ & $* *$ & $* * *$ \\
\hline Q & N.S. & N.S. & $\begin{array}{c}\text { N.S. } \\
\text { 2004-2005 }\end{array}$ & N.S. & N.S. \\
\hline $\mathrm{SsA}_{0}$ & $4.9 \mathrm{~d}$ & $52.3 \mathrm{~d}$ & $103.6 \mathrm{~d}$ & $5.6 \mathrm{c}$ & 1.94 \\
\hline $\mathrm{SsA}_{0.35}$ & $6.0 \mathrm{c}$ & $61.4 \mathrm{c}$ & $106.3 \mathrm{c}$ & $6.2 \mathrm{~b}$ & 2.95 \\
\hline $\mathrm{SsA}_{0.70}$ & $8.5 \mathrm{a}$ & $82.2 \mathrm{a}$ & $114.0 \mathrm{~b}$ & $7.0 \mathrm{a}$ & 3.81 \\
\hline $\mathrm{SsA}_{1.05}$ & $7.5 \mathrm{~b}$ & $69.6 \mathrm{~b}$ & $116.7 \mathrm{a}$ & $6.3 \mathrm{~b}$ & 2.99 \\
\hline$F$ & $* * *$ & $* * *$ & $* * *$ & $* *$ & $* * *$ \\
\hline $\mathrm{L}$ & $* * *$ & $* * *$ & $* * *$ & $* * *$ & $* * *$ \\
\hline Q & $*$ & $*$ & N.S. & * & $* *$ \\
\hline
\end{tabular}

Different letters within the same row show significant differences (LSD test, $P \leq 0.05$ ). Significance levels for linear (L) regression or quadratic (Q) term. *, **, ***, NS, significant difference at $P \leq 0.05,0.01,0.001$ and not significant, respectively. $\mathrm{F}$, variance ratio.

whereby such physiological changes are effected remain as yet unexplored.

In conclusion, we have shown that organic supplementation represents a management option which can be applied to improve the utility of soil solarization. Its adoption in commercial practice should be straightforward, and can be expected to be most beneficial in climatically marginal regions where the soil temperatures achieved by conventional solarization are not on their own high enough to provide an effective level of control of the soil biota. The strategy is fully compatible with organic production systems, and should be broadly applicable to the highly intensive agro-ecosystems characteristic of greenhouse-grown horticultural crops. An additional benefit stems from the possibility of reducing both the application rate of mineral fertilizers, and the duration of the solarization treatment. 

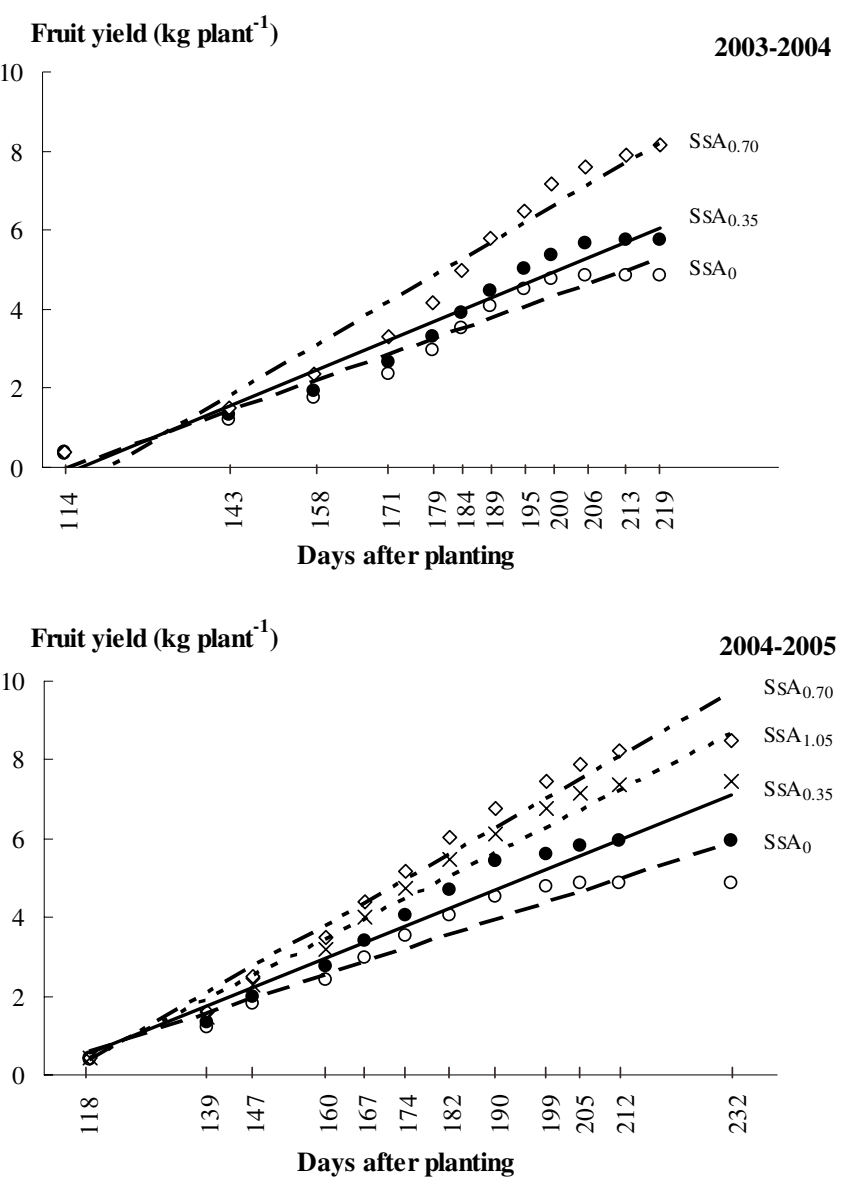

Figure 2. The relationship between fruit fresh weight and days after planting for three (2003-2004 season) and four (2004-2005 season) organic supplementation rates: $0\left(\mathrm{SsA}_{0}\right), 0.35\left(\mathrm{SsA}_{0.35}\right), 0.70$ $\left(\mathrm{SsA}_{0.70}\right)$ and $1.05\left(\mathrm{SsA}_{1.05}\right) \mathrm{kg} \mathrm{m}^{-2}$. Fruits were harvested at the red-ripe stage. Regression equations were: 2003-2004 $\left(\mathrm{SsA}_{0}: y=\right.$ $0.051 x-5.82, R^{2}=0.948 ; \mathrm{SsA}_{0.35}: y=0.059 x-6.96, R^{2}=0.956$; $\left.\mathrm{SsA}_{0.70}: y=0.081 x-10.22, R^{2}=0.953\right), 2004-2005\left(\mathrm{SsA}_{0}\right.$ : $y=0.046 x-4.85, R^{2}=0.922 ; \mathrm{SsA}_{0.35}: y=0.057 x-6.18, R^{2}=0.937$; $\mathrm{SsA}_{0.70}: y=0.081 x-9.24, R^{2}=0.966 ; \mathrm{SsA}_{1.05}: y=0.072 x-8.09$, $\left.R^{2}=0.957\right)$.

Acknowledgements: The authors thank the Azienda Agricola Fratelli Giardina for having hosted the experiment in their greenhouses and for their generous help in carrying out the trials, and Mr. Angelo Litrico and Miss Venera La Rosa for excellent technical assistance.

\section{REFERENCES}

Akhtar M., Malik A. (2000) Roles of organic soil amendments and soil organisms in the biological control of plant-parasitic nematodes: a review, Bioresour. Technol. 74, 35-47.

Assaf T.A., Hameed K.M., Turk M.A., Al-Tawaha A.M. (2006) Effect of soil amendment with olive mill by-products under soil solarization on growth and productivity of faba bean and their symbiosis with mycorrhizal fungi, World J. Agric. Sci. 2, 21-28.
Bacha N., Ayub N., Ahmad Y., Abbas M., Rafi A. (2007) Soil solarization: a safe, affective and practicable technique for the control of soil born fungi e nematodes, Pakistan J. Biol. Sci. 10, 57-64.

Chen Y., Gamliel A., Stapleton J.J., Aviad T. (1991) Chemical, physical, and microbial changes related to plant growth in disinfested soils, in: Katan J., DeVay J.E. (Eds.), Soil solarization. CRC Press, Boca Raton, FL, pp. 103-129.

Chen Y., Katan J., Gamliel A., Aviad T., Schnitzer M. (2000) Involvement of soluble organic matter in increased plant growth in solarized soil, Biol. Fertil. Soils 32, 28-34.

Gamliel A., Stapleton J.J. (1993) Effect of chicken compost or ammonium phosphate and solarization on pathogen control, rhizosphere microorganism, and lettuce growth, Plant Disease 77, 886-891.

Gamliel A., Stapleton J.J. (1997) Improved soil disinfestation by biotoxic volatile compounds generated from solarized, organic amended soil, in: Grinstein A., Ascher K.R.S., Mathews G., Katan J., Gamliel A. (Eds), Improved Application Technology for Reduction of Pesticide Dosage and Environmental Pollution, Phytoparasitica 25 Suppl. 1, 31-38.

Gamliel A., Austerweil M., Kritzman G. (2000) Non-chemical approach to soilborne pest management - organic amendments, Crop Prot. $19,847-853$.

Gazzetta Ufficiale (1992) Metodi ufficiali di analisi chimica dei suoli, D.M. 11 maggio 1992, Suppl. G.U., 121.

Gelsomino A., Cacco G. (2006) Compositional shifts of bacterial groups in a solarized and amended soil as determined by denaturing gradient gel electrophoresis, Soil Biol. Biochem. 38, 91-102.

Gelsomino A., Badalucco L., Landi L., Cacco G. (2006) Soil carbon, nitrogen and phosphorus dynamics as affected by solarization alone or combined with organic amendment, Plant Soil 279, 307-325.

Grünzweig J.M., Katan J., Ben-Tal Y., Rabinowitch H.D. (1999) The role of mineral nutrients in the increased growth response of tomato plants in solarized soil, Plant Soil 206, 21-27.

ISTAT Istituto nazionale di Statistica Agraria 2006, 2007, Roma, Italy, http://www.istat.it.agricoltura/datiagri/coltivazioni/.

Katan J. (2000) Soil and substrate disinfestation as influenced by new technologies and constraints, Acta Hortic. 532, 29-35.

Katan J., Grinstein A., Greenberger A., Yarden O., DeVay J.E. (1987) The first decade (1976-1986) of soil solarization (solar heating): a chronological bibliography, Phytoparasitica 13, 229-255.

Le Bihan B., Soulas M.L., Camporota P., Salerno M.I., Perrin R. (1997) Evaluation of soil solar heating for control of damping-off fungi in two forest nurseries in France, Biol. Fertil. Soils 25, 189-195.

Mahrer Y. (1979) Prediction of soil temperature of a soil mulched with transparent polyethylene, J. Appl. Meteorol. 18, 1263-1267.

Mauromicale G., Lo Monaco A., Longo A.M.G., Restuccia A. (2005a) Soil solarization, a non-chemical method to control branched broomrape (Orobanche ramosa) and improve the yield of greenhouse tomato, Weed Sci. 53, 877-883.

Mauromicale G., Marchese M., Restuccia A., Sapienza O., Restuccia G., Longo A.M.G. (2005b) Root nodulation and nitrogen accumulation and partitioning in legume crops as affected by soil solarization, Plant Soil 271, 275-284.

Montreal Amendment (1997) http://ozone.unep.org/Ratification_status/ montreal_amendment.shtml.

Noling J.W., Becker J.O. (1994) The challenge of research and extension to define and implement alternatives to methyl bromide, Suppl. J. Nematol. 26, 573-586.

Oka Y., Shapira N., Fine P. (2007) Control of root-knot nemeatodes in organic farming systems by organic amendments and soil solarization, Crop Prot. 26, 1556-1565. 
Ottaviano E. (1977) Regressione e correlazione, in: Piccin E. (Ed.), Biometria Principi e Metodi. Padova, Italy, pp. 274-278.

Ozores-Hampton M., Stansly P.A., McSorley R., Obreza T.A. (2005) Effect of long term organic amendments and soil solarization on pepper and watermelon growth, yield, and soil fertility, HortScience 40, 80-84.

Piedra-Buena A., García-Alvarez A., Díez-Rojo M.A., Ros A., Fernández P., Lacasa A., Bello A. (2007) Use of pepper crop residues for the control of root-knot nematodes, Bioresour. Technol. 98, 2846-2851.

Servizio idrografico (1959-1998) Annali idrologici, Regione Sicilia, Assessorato dei lavori pubblici, Palermo, Italy.

SISS Società Italiana Scienza del Suolo (1985) Metodi normalizzati di analisi del suolo, Edagricole, Bologna, Italy, p. 100.
Stapleton J.J., Quick J., De Vay J.E. (1985) Soil solarization: effects on soil properties, crop fertilization and plant growth, Soil Biol. Biochem. 17, 369-373.

Stotzky G. (1974) Activity, ecology and population dynamics of microorganisms in soil, in: Laskin A., Lechvalier H. (Eds.), Microbial ecology, CRC Press, Cleveland, Ohio, pp. 57-135.

Thuriès L., Larreé-Larrouy M.C., Feller C. (2000) Influence of organic fertilization and solarization in a greenhouse on particle-size fraction of a Mediterranean sandy soil, Biol. Fertil. Soils 32, 449-457.

Tognoni F., Serra G. (2003) Trends in Process Technologies and Products, Acta Hortic. 614, 65-75.

UNICHIM (1985) Analisi dei terreni agrari, Unichim, Milano, Italy. 